\title{
A Study on the Effects of Word-of-Mouth on Brand Trust in Tourism Industry
}

\author{
Monica Shu-Fen $\mathrm{Wu}^{1 *}$ \\ ${ }^{1}$ Department of Hospitality Management, Wu Feng University, TAIWAN, R.O.C.
}

Received 30 May 2017 - Revised 18 September 2017 - Accepted 6 October 2017

\begin{abstract}
From the statistical data of World Tourism Organization on the number and average growth of travelers and the travel income, Asia-Pacific Region presents the best potential in tourism markets. A lot of visitors would choose to receive information through Word-of-Mouth when planning a tour. The Word-of-Mouth experiences and shared information could induce a visitor's travel demands. It therefore becomes a primary issue for the marketing in tourism industry to understand the function of Word-of-Mouth on a visitor's trust and employment of a tourism business brand. Taking EasyTravel as the research subject, the questionnaire survey is preceded through e-mails. With convenience sampling, total 1000 copies of questionnaires are distributed to the web members of EasyTravel, and 382 valid copies are retrieved, with the retrieval rate $38 \%$. The research results show the significantly positive correlations between 1.Word-of-Mouth and Brand Reliability in Brand Trust and 2.Word-of-Mouth and Brand Intention in Brand Trust; besides, 3.demographic variables reveal remarkable effects on the correlations between Word-of-Mouth and Brand Trust.
\end{abstract}

Keywords: marketing, brand image, tourism management, brand intention, oral suggestion

\section{INTRODUCTION}

\section{Research Motivation}

The construction of tourism and recreation environments and the promotion of leisure concepts have enhanced citizen demands for the quality and quantity of outdoor recreation. A lot of visitors therefore would arrange trips during two-day weekends or holidays. Chang, Kivela \& Mak (2011) indicated that consumers were used to acquire product information through blogs and online forums and were willing to share knowledge or information with others. In this case, many visitors among such enormous travelers would utilize the Internet to search for tourism information for the reference.

Tourism and recreational travel have become a good way of releasing pressure for many people. Before choosing a destination, people would refer to many books and travel programs and reports on TV, or look for relative data to one or several destinations, and then make the most appropriate decision. However, the sources of such information are wondered. Choi \& Lee (2009) mentioned that consumers were in an information asymmetric situation when the media were not open and the Internet was not popular so that the product information was restricted to media advertisement or enterprise announcement.

Such information was a one-way communication from an enterprise to customers, who therefore needed more Word-of-Mouth opinions for the real information of products. For this reason, the effects of Word-of-Mouth on tourism industry become the major discussion in this study. 


\section{Contribution of this paper to the literature}

- A tourism business should understand the real opinions and demands of customers and create strong brand image to differentiate from other competitive businesses. A consumer does not simple purchase a tourism product with the functional demands, but might have the product or brand image stand for the consumer to generate Purchase Intention.

- A tourism business should devote to the quality control. Once the product quality is affirmed, Word-ofMouth of the brand would be established and the business would receive high fame and high evaluation that the relative advertising and marketing expenses would be reduced when promoting new tourism products.

- A tourism business should pay attention to the perceived value of services, focus on reasonable prices and customer agreement with the product services. As a consequence, consumer demands for tourism products should be clearly understood and entity tourism products or services should be delivered to different consumers in order to satisfy the needs and enhance Word-of-Mouth and Brand Trust.

\section{Literature Review}

\section{Word-of-Mouth}

Word-of-Mouth is the free oral and person-to-person discussions and communications among consumers involving in brand, products, or services in the market or consumption-related affairs, where the receivers perceived the propagation being non-commercial (Dey and Sarma 2010). Chen \& Mo (2012) regarded Word-ofMouth as an oral spreading behavior, referring to people-centered information propagation, which was the noncommercial communication or recommendation of products, brand, or services. Horng, Liu, Chou \& Tsai (2012) defined Word-of-Mouth as a person acquiring consumption experiences of others through the dynamic interaction in the social relationship network, rather than through investigation.

Jacobsen \& Munar (2012) considered Word-of-Mouth as the overall comment of a brand, the sum of comments of certain products, services, or among people in a company. Different from traditional marketing, Word-of-Mouth would change the market point from the relationship between brand and individual customer to the interaction among customers. Moreover, Oral Suggestion did not present commercial motivation that consumers would consider Oral Suggestion with higher reliability than advertisement (Kang and Gretzel 2012). Some researchers discovered that consumers would depend on others' opinions when evaluating a new product or a new service (Kim \& Lee, 2011); or, the effects among people would became critical when a product complexity was enhanced and objective and specific evaluation criteria were insufficient (Hsu, 2016). Overall speaking, a consumer would look for Word-of-Mouth information to make decisions when facing information overload and high perceived risk, evaluating new product, selecting professional service providers, and product complexity being increased but lack of objective and specific evaluation criteria (Lee and Lee 2009).

Referring to Li, Meng, Uysal \& Mihalik (2013), Word-of-Mouth, based on involvement, is divided into (1) Product Involvement, showing a user tending to discuss about a purchase experience and the acquired pleasure, (2) Ego-Involvement, referring to user experiences in certain purchase in order to seek for attention, identity, or concerns from others, and (3) Other Involvement, revealing a user sharing the knowledge or experiences to help other consumers.

\section{Brand Trust}

The past research showed that trust could be discussed from different aspects, such as psychology, sociology, economics, management, and marketing (Ha \& Fang, 2012). From the aspect of marketing, trust contains brand, products, services, sales staff, and the selling and purchase of products or services (Hung and Petrick 2012). Trust has been a key factor in permanently remaining favorable relationship (Jalilvand et al. 2012). Kerckhove, Geuens \& Vermeir (2012) pointed out Brand Trust as general consumers believing in the practical value of a brand. Lee, Song, Bendle, Kim \& Han (2012) defined Brand Trust as a consumer being glad to depend on a brand to achieve the designated function. Milman (2011) defined Brand Trust as the degree of a consumer believing in the ability of a brand presenting the claimed function. When a consumer believed in the products provided by a brand presenting good quality and high reliability and stressed on not understanding and not being able to select a product, Brand Trust could reduce the uncertainty about the product.

Wong \& Liu (2011) mentioned that trust was gradually discussed individually and was often discussed with brand in the past years. For example, a consumer revealing high trust on a brand, i.e. Brand Trust, also meant that the consumer believed in the product quality, services, image, or other intangible attributes of the brand, such as 
the claimed value and status. Brand Trust could reinforce consumer confidence and allowed a consumer considering the decision being correct (Nicoletta \& Servidio, 2012). Qu, Kim \& Im (2011) also indicated that Brand Trust referred to the degree of a consumer believing in the practical value of a brand; besides, trust could reduce consumer uncertainty and enhance consumer being willing to actively purchase, as the consumer perceived the brand being reliable and considered reliable, safe, and honest consumption situations as the key in Brand Trust. Rozier-Rich \& Santos (2011) pointed out Brand Trust as a consumer being willing to believe in the claimed functions of a brand. When a consumer was willing to believe in the product quality offered by a brand being favorable and reliable and emphasized the correlations between trust and uncertainty, such as not understanding and hard to select a product, Brand Trust could reduce the uncertainty in the transaction and further build favorable relationship (Liu, \& Yen, 2014).

Referring to Sheng \& Chen (2012), Brand Trust is divided into two dimensions in this study. Brand Reliability refers to expecting the transactional subject being reliable and the claimed contents being worthy of trust and being able to satisfy customer demands. Brand Intention refers to the transactional subject really caring about consumer benefits that the transaction could reoccur merely when a consumer clearly perceived the honesty and the security of a brand.

\section{Research on the correlations between Word-of-Mouth and Brand Trust}

Lee, Yeung \& Dewald (2010) indicated that Word-of-Mouth was a key factor in a family making decisions on purchasing products and food. Mutinda \& Mayaka (2012) discovered that about $60 \%$ of new customers consuming in a company was influenced by Word-of-Mouth. Word-of-Mouth was a face-to-face and non-commercial communication behavior among people to affect a consumer's evaluation and consumption intention through information exchange of a specific product or service (Parra et al. 2011). Rittichainuwa \& Mair (2011) mentioned that Brand Trust was established based on the enterprise reputation, and favorable reputation could reinforce consumer confidence as well as enhance the loyalty or purchase intention. It reveals that Word-of-Mouth would affect consumer trust for an enterprise and would indirectly influence the behavioral intention (Scarinci and Pearce 2012). Whitfield \& Webber (2011) also pointed out the positive effects of Word-of-Mouth on consumer perceived value, which would further influence Brand Trust, that Word-of-Mouth could affect Brand Trust.

According to above points of view, the following hypotheses are proposed in this study.

H1: Word-of-Mouth presents significantly positive correlations with Brand Reliability in Brand Trust.

H2: Word-of-Mouth shows remarkably positive correlations with Brand Intention in Brand Trust.

H3: Gender reveals notable moderating effects on the correlations between Word-of-Mouth and Brand Trust.

H4: Age appears significant moderating effects on the correlations between Word-of-Mouth and Brand Trust.

H5: Educational Background presents remarkable moderating effects on the correlations between Word-ofMouth and Brand Trust.

H6: Marital Condition shows notable moderating effects on the correlations between Word-of-Mouth and Brand Trust.

\section{METHODOLOGY}

\section{Research Framework}

From the literatures on the correlations between Word-of-Mouth and Brand Trust, the research framework is proposed to discuss the correlations between Word-of-Mouth and Brand Trust as following Figure1: 


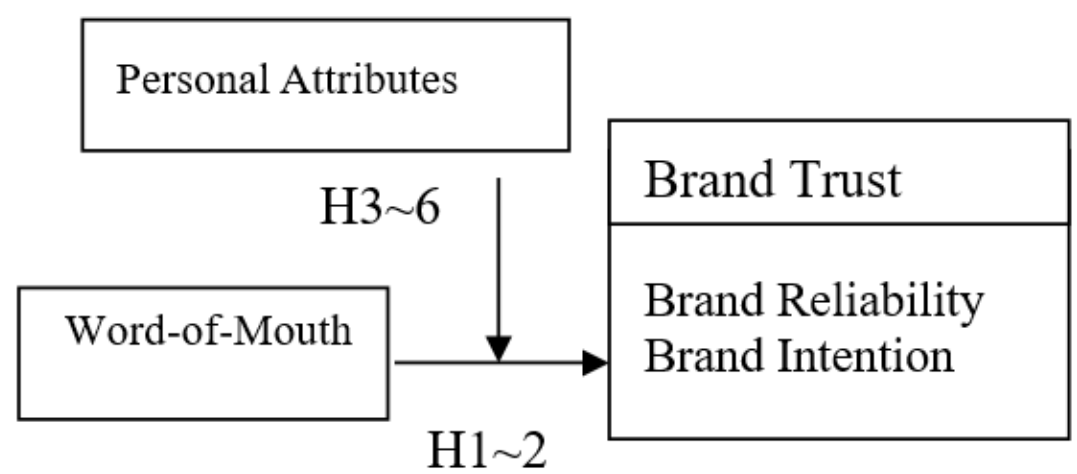

Figure 1. Research framework

\section{Research Subject and Sampling}

EasyTravel is selected as the research subject. Started in information industry, EasyTravel was established in April 1999, focusing on Free Tour in Taiwan. By 2000, total 3000 hotels in Taiwan were visited, and EasyTravel was ranked the 152 in top 500 web sites and the second in Travel category by Business Weekly. With the continuous efforts, EasyTravel presented high-quality e-commerce website on Innovative Operation Model and Customer Reliable Business in 2010 and awarded silver award in the 10th e-21 Golden Website Award of Department of Commerce, Ministry of Economic Affairs. It also awarded the excellent company in 2011 Regional Small Business Innovation Research in Kaohsiung City by Economic Development Bureau, Kaohsiung City Government, in 2012. It promoted mobile booking APP in the end of 2010 with excellence. By combining the services of computers and smart phones, the consumers could rapidly and conveniently inquire travel data; and, various ways of payment allow the consumers easily complete the payment and transaction. By the end of 2013, about 2000 cooperative hotels, nearly 80000 pieces of travel spots/schedule and activity information, more than 0.5 million people applying for the account of EasyTravel, more than 0.73 million pieces of weekly e-news being transmitted, more than 5.5 million web visitors, and more than 45 million clicks per month were accumulated. The questionnaires are distributed and collected through e-mails. With convenience sampling, the members of EasyTravel are distributed 1000 copies of questionnaires, and 382 valid copies are retrieved, with the retrieval rate $38 \%$. Among the valid copies of questionnaires, males and females appear $46 \%$ and $54 \%$, respectively; the age groups of 21-30, 31-40, and $41-50$ reveal 51\%, 22\%, 12\%, and 7\%, respectively; the educational background of senior (vocational) high school, college, and graduate school show $23 \%, 47 \%$, and $24 \%$, respectively; and, married people present $32 \%$ and unmarried ones $58 \%$.

\section{Reliability and Validity Analysis}

With Confirmatory Factor Analysis (CFA), the Word-of-Mouth scale was extracted three factors with the eigenvalue larger than 1, including Product Involvement (eigenvalue=2.462, a=0.83), Ego-Involvement (eigenvalue $=1.877, \mathrm{a}=0.81$ ), and Other Involvement (eigenvalue $=1.513, \mathrm{a}=0.86$ ). The covariance explained reached $80.394 \%$.

With Factor Analysis, the Brand Trust scale was extracted two factors of Brand Reliability (eigenvalue=3.175, $\mathrm{a}=0.88$ ) and Brand Intention (eigenvalue $=2.952, \mathrm{a}=0.82$ ). The covariance explained achieved $84.082 \%$.

\section{Correlation Analysis}

1. Correlation Analysis of Word-of-Mouth and Brand Reliability in Brand Trust

Applying Regression Analysis to testing H1, the analysis results, Table 1, presented the significance of the regression equation $(\mathrm{F}=12.746, \mathrm{p}<0.000)$. Word-of-Mouth showed significant effects on Brand Reliability, where Product Involvement, Ego-Involvement, and Other Involvement in Word-of-Mouth revealed remarkably positive effects on Brand Reliability in Brand Trust, reaching the significance $(\beta=0.227, p<0.01 ; \beta=0.212, p<0.01 ; \beta=0.178$, $\mathrm{p}<0.05$. H1 was therefore supported. 
Table 1. Regression Analysis of Word-of-Mouth and Brand Trust

\begin{tabular}{|c|c|c|}
\hline & \multicolumn{2}{|c|}{ Brand Trust (Dependent variable) } \\
\hline & Brand Reliability & Brand Intention \\
\hline \multicolumn{3}{|c|}{ Word-of-Mouth (Independent variable) } \\
\hline Product Involvement & $0.227^{* *}$ & $0.193^{*}$ \\
\hline Ego-Involvement & $0.212^{* *}$ & $0.206^{\star \star}$ \\
\hline Other Involvement & $0.178^{*}$ & $0.168^{*}$ \\
\hline $\mathrm{F}$ & 12.746 & 23.945 \\
\hline Significance & $0.000^{\star \star \star}$ & $0.000^{\star * \star}$ \\
\hline $\mathrm{R} 2$ & 0.238 & 0.327 \\
\hline Adjusted R2 & 0.034 & 0.045 \\
\hline${ }^{*} \mathrm{p}<0.05^{* *} \mathrm{p}<0.01{ }^{* * *} \mathrm{p}<0.001$ & & \\
\hline
\end{tabular}

Table 2. Effects of Gender on the correlations between Word-of-Mouth and Brand Trust

\begin{tabular}{ccc}
\hline Word-of-Mouth & Brand Reliability & Brand Intention \\
\hline Product Involvement & $\mathrm{p}>0.05$ & $\mathrm{p}<0.01$ \\
\hline Ego-Involvement & $\mathrm{p}<0.01$ & $\mathrm{p}>0.05$ \\
\hline Other Involvement & $\mathrm{p}<0.05$ & $\mathrm{p}<0.05$ \\
\hline Hypothesis test & H3 partially supported \\
\hline
\end{tabular}

Table 3. Effects of Age on the correlations between Word-of-Mouth and Brand Trust

\begin{tabular}{ccc}
\hline Word-of-Mouth & Brand Reliability & Brand Intention \\
\hline Product Involvement & $\mathrm{p}<0.05$ & $\mathrm{p}<0.05$ \\
\hline Ego-Involvement & $\mathrm{p}>0.05$ & $\mathrm{p}>0.05$ \\
\hline Other Involvement & $\mathrm{p}<0.01$ & $\mathrm{p}>0.05$ \\
\hline Hypothesis test & & H4 partially supported \\
\hline
\end{tabular}

\section{RESULTS}

\section{Correlation Analysis of Word-of-Mouth and Brand Intention in Brand Trust}

Applying Regression Analysis to testing H2, the analysis results, Table 1, showed the significance of the regression equation $(\mathrm{F}=23.945, \mathrm{p}<0.000)$. Word-of-Mouth appeared notable effects on Brand Intention, where Product Involvement, Ego-Involvement, and Other Involvement in Word-of-Mouth presented significantly positive effects on Brand Intention in Brand Trust, achieving the significance $(\beta=0.193, p<0.05 ; \beta=0.206, p<0.01$; $\beta=0.168, \mathrm{p}<0.05)$, that $\mathrm{H} 2$ was supported.

\section{DISCUSSION}

\section{Moderating Effects of Demographic Variable}

\section{Effects of Gender on the correlations between Word-of-Mouth and Brand Trust}

The empirical Analysis of Variance, Table 2, showed the remarkable effects of Gender on the correlations between Ego-Involvement $(p<0.01)$, Other Involvement $(p<0.05)$ and Brand Reliability and between Product Involvement $(\mathrm{p}<0.01)$, Other Involvement $(\mathrm{p}<0.05)$ and Brand Intention. In this case, H3 was partially supported.

\section{Effects of Age on the correlations between Word-of-Mouth and Brand Trust}

The empirical Analysis of Variance, Table 3, presented the remarkable effects of Age on the correlations between Product Involvement $(\mathrm{p}<0.05)$, Other Involvement $(\mathrm{p}<0.01)$ and Brand Reliability and between Product Involvement $(\mathrm{p}<0.05)$ and Brand Intention that $\mathrm{H} 4$ was partially supported. 
Table 4. Effects of Educational Background on the correlations between Word-of-Mouth and Brand Trust

\begin{tabular}{ccc}
\hline Word-of-Mouth & Brand Reliability & Brand Intention \\
\hline Product Involvement & $\mathrm{p}>0.05$ & $\mathrm{p}>0.05$ \\
\hline Ego-Involvement & $\mathrm{p}<0.01$ & $\mathrm{p}>0.05$ \\
\hline Other Involvement & $\mathrm{p}>0.05$ & $\mathrm{p}<0.01$ \\
\hline Hypothesis test & \multicolumn{3}{c}{ H5 partially supported } \\
\hline
\end{tabular}

Table 5. Effects of Marital Condition on the correlations between Word-of-Mouth and Brand Trust

\begin{tabular}{ccc}
\hline Word-of-Mouth & Brand Reliability & Brand Intention \\
\hline Product Involvement & $\mathrm{p}>0.05$ & $\mathrm{p}<0.05$ \\
\hline Ego-Involvement & $\mathrm{p}>0.05$ & $\mathrm{p}<0.05$ \\
\hline Other Involvement & $\mathrm{p}<0.01$ & $\mathrm{p}>0.05$ \\
\hline Hypothesis test & H6 partially supported & \\
\hline
\end{tabular}

\section{Effects of Educational Background on the correlations between Word-of-Mouth and Brand Trust}

The empirical Analysis of Variance, Table 4, revealed the notable effects of Educational Background on the correlations between Ego-Involvement $(p<0.01)$ and Brand Reliability and between Other Involvement $(p<0.01)$ and Brand Intention. Accordingly, H5 was partially supported.

\section{Effects of Marital Condition on the correlations between Word-of-Mouth and Brand Trust}

The empirical Analysis of Variance, Table 5, appeared significant effects of Marital Condition on the correlations between Other Involvement $(\mathrm{p}<0.01)$ and Brand Reliability and between Product Involvement $(\mathrm{p}<0.05)$, Ego-Involvement $(\mathrm{p}<0.05)$ and Brand Intention that H6 was partially supported.

\section{CONCLUSION}

The research results present the remarkable effects of Word-of-Mouth on Brand Trust. Finally, it is verified that demographic variables reveal moderating effects on the correlations between Word-of-Mouth and Brand Trust. Accordingly, $\mathrm{H} 1$ and $\mathrm{H} 2$ are supported, while $\mathrm{H} 3 \sim \mathrm{H} 6$ are partially supported.

Apparently, brand is not simply a brand, but the mark and commitment of business reputation guaranteeing the consumers and achieving the differentiation among various competitors. Tourism businesses with excellent brand image therefore would have the consumers associate with the product name, product quality, and Brand Trust when selecting a tourism business, which could assist the consumers in the evaluation and enhance the confidence in the tourism products. A tourism business with favorable image would present complete after-sales services so that the customers could confidently consume and appear higher Purchase Intention. A lot of research findings showed the great effects of Word-of-Mouth on consumer behaviors, which would affect the brand image of a product and the purchase decision of a consumer. Word-of-Mouth is a non-commercial communication behavior in exchanging and discussing a specific product or service among people. The introduction of tourism products through advertisement and marketing personnel with the Word-of-Mouth information would be more reliable for consumers. When such information is positive to the tourism business, the consumers would appear higher Brand Trust.

\section{RECOMMENDATIONS}

Summing up the data analyses and research conclusion in this study, suggestions for practical applications of Word-of-Mouth and further research are proposed. Similar tourism products are full of currently competitive mobile phone markets. A tourism business should understand the real opinions and demands of customers and create strong brand image to differentiate from other competitive businesses. A consumer does not simple purchase a tourism product with the functional demands, but might have the product or brand image stand for the consumer to generate Purchase Intention. A tourism business therefore could appeal consumers through media and change the viewpoints of a consumer towards the tourism business brand and product through designed advertisement. For instance, when the target customers are the rich, the advertisement could be elegant and dignified so that the consumers perceive the product being able to represent their status to enhance Purchase Intention. 
In addition to select tourism products for showing the social and economic status and group identity, the function and quality of a tourism product are the options. A consumer would generally consider a brand with favorable Word-of-Mouth presenting excellent and reliable product quality. For this reason, a tourism business should devote to the quality control. Once the product quality is affirmed, Word-of-Mouth of the brand would be established and the business would receive high fame and high evaluation that the relative advertising and marketing expenses would be reduced when promoting new tourism products.

In addition to create Word-of-Mouth, a tourism business should constantly develop new tourism products and maintain the product quality. After all, products are the basis of a brand; without excellent products, the brand would not be sustained. A tourism business should also stress on the consumption process of a consumer. Some consumers might emphasize more on the pleasure in the purchase process that they expect an entire set of services, such as attractive advertisement, complete product information, and excellent after-sales services. In other words, a tourism business should pay attention to the perceived value of services, focus on reasonable prices and customer agreement with the product services. As a consequence, consumer demands for tourism products should be clearly understood and entity tourism products or services should be delivered to different consumers in order to satisfy the needs and enhance Word-of-Mouth and Brand Trust.

\section{REFERENCES}

Chang, R. C. Y., Kivela, J., \& Mak, A. H. N. (2011). Attributes that influence the evaluation of travel dining experience: When east meets west. Tourism Management, 32, 307-316.

Chen, Y. F., \& Mo, H. E. (2012). Attendees' perspectives on the service quality of an exhibition organizer: A case study of a tourism exhibition. Tourism Management Perspectives, 1, 28-33.

Choi, H. S. C., \& Lee, S. (2009). Understanding US traveler behavior to Asian countries: A secondary analysis approach. Asia Pacific Journal of Tourism Research, 14(3), 279-299.

Dey, B., \& Sarma, M. K. (2010). Information source usage among motive-based segments of travelers to newly emerging tourist destinations. Tourism Management, 31, 341-344.

Ha, L., \& Fang, L. (2012). Internet experience and time displacement of traditional news media use: An application of the theory of the niche. Telematics and Informatics, 29(2), 177-186.

Horng, J. S., Liu, C. H., Chou, H. Y., \& Tsai, C. Y. (2012). Understanding the impact of culinary brand equity and destination familiarity on travel intentions. Tourism Management, 33, 815-824.

Hsu, M. W. (2016). An Analysis of Intention to Use in Innovative Product Development Model through TAM Model. Eurasia Journal of Mathematics, Science \& Technology Education, 12(3), 487-501.

Hung, K., \& Petrick, J. F. (2012).Testing the effects of congruity, travel constraints, and self-efficacy on travel intentions: An alternative decision-making model. Tourism Management, 33, 855-867.

Jacobsen, J. K. S., \& Munar, A. M. (2012).Tourist information search and destination choice in a digital age. Tourism Management Perspectives, 1, 39-47.

Jalilvand, M. R., Samiei, N., Dini, B., \& Manzari, P. Y. (2012). Examining the structural relationships of electronic word of mouth, destination image, tourist attitude toward destination and travel intention: An integrated approach. Journal of Destination Marketing EManagement, 1, 134-143.

Kang, M., \& Gretzel, U. (2012). Effects of podcast tours on tourist experiences in a national park. Tourism Management, 33, 440-455.

Kerckhove, A. V., Geuens, M., \& Vermeir, I. (2012). Intention superiority perspectives on preference-decision consistency. Journal of Business Research, 65(5), 692-700.

Kim, Y. K., \& Lee, H. R. (2011).Customer satisfaction using low cost carriers. Tourism Management, 32, 235-243.

Lee, C. K., Song, H. J., Bendle, L. J., Kim, M. J., \& Han, H. (2012).The impact of non-pharmaceutical interventions for 2009 H1N1 influenza. Tourism Management, 33, 89-99.

Lee, G., \& Lee, C. K. (2009). Cross-cultural comparison of the image of Guam perceived by Korean and Japanese leisure travelers: Importance-performance analysis. Tourism Management, 30, 922-931.

Lee, M. J., Yeung, S., \& Dewald, B. (2010). An exploratory study examining the determinants of attendance motivations as perceived by attendees at Hong Kong exhibitions. Journal of Convention and Event Tourism, 11, 195-208.

Li, X., Meng, F. M., Uysal, M. U., \& Mihalik, B. (2013). Understanding Chinas long-haul outbound travel market: An overlapped segmentation approach. Journal of Business Research, 66, 786-793.

Liu, H. C., \& Yen, J. R. (2014). Effects of Distance Learning on Learning Effectiveness. Eurasia Journal of Mathematics, Science E Technology Education, 10(6). 
Milman, A. (2011). The symbolic role of postcards in representing a destination image: The case of Alanya, Turkey. International Journal of Hospitality $\mathcal{E}$ Tourism Administration, 12, 144-173.

Mutinda, R., \& Mayaka, M. (2012). Application of destination choice model: Factors influencing domestic tourists destination choice among residents of Nairobi, Kenya. Tourism Management, 33, 1593-1597.

Nicoletta, R., \& Servidio, R. (2012). Tourists' opinions and their selection of tourism destination images: An affective and motivational evaluation. Tourism Management Perspectives, 4, 19-27.

Parra, L. E., Bulchand, G. J., Gutiérrez, T. D., \& Díaz, A. R. (2011). Intentions to use social media in organizing and taking vacation trips. Computers in Human Behavior, 27, 640-654.

Qu, H., Kim, L. H., \& Im, H. H. (2011). A model of destination branding: Integrating the concepts of the branding and destination image. Tourism Management, 32, 465-476.

Rittichainuwa, B., \& Mair, J. (2011). Visitor attendance motivations at consumer travel exhibitions. Tourism Management, 33, 1236-1244.

Rozier-Rich, S., \& Santos, C. A. (2011). Processing promotional travel narratives. Tourism Management, 32, $394-405$.

Scarinci, J., \& Pearce, P. (2012). The perceived influence of travel experiences on learning generic skills. Tourism Management, 33, 380-386.

Sheng, C. W., \& Chen, M. C. (2012). A study of experience expectations of museum visitors. Tourism Management, $33,53-60$.

Whitfield, J., \& Webber, D. J. (2011). Which exhibition attributes create repeat visitation? International Journal of Hospitality Management, 30, 439-447.

Wong, C. K. S., \& Liu, F. C. G. (2011). A study of pre-trip use of travel guidebooks by leisure travelers. Tourism Management, 32, 616-628.

\section{http://www.ejmste.com}

